\title{
IAMJ
}

INTERNATIONAL AYURVEDIC MEDICAL JOURNAL

\section{EMPOWERMENT OF MENTAL HEALTH THROUGH SATTVAVJAYA CHIKITSA}

\author{
$\underline{\text { Desai Tanvi Prashant }^{1}}, \underline{\text { Kolarkar Rajesh }}^{2}, \underline{\text { Bande Mahendra }}^{3}$
}

${ }^{1}$ M.D. Scholar, Ayurved Samhita and Siddhanta Department, YMT Ayurvedic Medical College, Hospital \& PG Institute, Kharghar, Navi Mumbai, Maharashtra, India

${ }^{2}$ Professor, HOD, Ayurved Samhita and Siddhanta Department, YMT Ayurvedic Medical College, Hospital \& PG Institute, Kharghar, Navi Mumbai, Maharashtra, India

${ }^{3}$ Professor, Gramin Ayurved College, Patur, Maharashtra, India

Corresponding Author: desaitanvi01@yahoo.com

\section{https://doi.org/10.46607/iamj12p5052021}

(Published online: July 2021)

Open Access

(C) International Ayurvedic Medical Journal, India 2021

Article Received: 26/07/2021 - Peer Reviewed: 27/07/2021 - Accepted for Publication: 28/07/2021

Check for updates

\begin{abstract}
Ayurveda has been one of the oldest medicinal systems in the world. Ayurveda focuses on the promotive as well as curative aspects of wellbeing. Ayurveda happens to manage both, physical as well as mental illnesses in normal and abnormal forms. The system believes in the psychosomatic aspect of every disease. Thus, focusing on the development, empowerment and maintenance of the mental health status of a human being is a top priority nowadays. The current day scenario also demands a strong spotlight over mental health awareness and development. Acharya Charaka has mentioned a salient feature known as Sattvavajaya chikitsa in the classical text well versed with the techniques to use for the maintenance of a healthy state of Mind. Mental health refers to cognitive, behavioural, and emotional well-being. It is all about how people think, feel, and behave. This Article attempt is being made to combine the mentioned techniques in one single place. The main aim of SATTVAVAJAYA CHIKITSA is to restrain the mind from the unwanted thought process, replacing negative ideas, proper channelling of presumptions and proper advice through Jnanam (Knowledge), Vijayan (analytical thinking), dhairya (courage), smriti (memory) and samadhi (concentration). The practice of Achara rasayana reduces stress and anxiety improves psychoneurotic immunity. Components of Sattvavajaya chikitsa are Dinacharya (daily regimen), Ritucharya (Seasonal regimen), Sadvritta (code of virtues)/Achara Rasayana Roganutpadana (Prevention of diseases), Annapanavidhi (Rules about food and drinks).
\end{abstract}

Keywords: Sattvavajaya Chikitsa, Mental Health, Modern Psychotherapy, Sadvrutta, Aachaar Rasayan. 


\section{INTRODUCTION}

Ayurveda is regarded as "The Science of Life" and the system involves the physical, mental, and spiritual wellbeing as major components. The term 'Empowerment' was used by W.H.O. in one of its projects back in 2010 which was defined as, "the level of choice, influence and control that user of mental health services can exercise over events in their lives." It implies people being empowered to promote their well-being and be interactive regarding their problems. Empowerment can be developed in various manners by being non-judgmental and respectful, creating a comfortable atmosphere for the patient to be able to discuss their feelings, focusing on their strengths and abilities and respecting the decisions they make for their own life. Empowerment is a person-centered holistic approach.

Ayurveda mentions three types of treatment protocols for all disorders, viz. Daivyavapashraya, Yuktivyapashraya and Sattvavajaya chikitsa. The Sattvavajaya chikitsa is mentioned by Acharya Charak in his classical text. The Charaka Samhita includes widespread information on this form of chikitsa. Sattvavajaya chikitsa is not merely a form of treatment, but it is meant to be used for the maintenance of the mental health of a human being as well. The definition of Sattvavajaya chiktsa is, "Satvavajaya Punah Ahitebhyo Arthebhyo Manognigrah". (Ch. Su. 11/54). The term Manonigraha means mental restraint or control over the mind. The mental restraint can be achieved by, "Manaso Jnana, Vijnana, Dhairya, Smriti, Samadhibhih ". (Ch. Su. 1/58) ", viz. Gyan (spiritual knowledge), Vijnana (skilled/textual knowledge), Dhairya (patience \& will power), Smriti (remembrance) and Samadhi (concentration). The methods of Sattvavjaya chikitsa also include a) Ashwasana- assurance to the patient and b) Pratidhwanda Chikitsa- inducement of opposite emotions to the associated ones with the person's distress. There is no harm in correlating Acharaya Charaka's Sattvavajaya chiktsa with modern psychotherapy. The comprehensive definition of Psychotherapy given by Wolberg states that "Psychotherapy is the treatment, by psychological means, of the problem of an emotional nature in which a trained person deliberately establishes a professional relationship with the patient with the object of removing, modifying, or retarding existing symptoms, mediating disturbed patterns of behaviour, and promoting positive personality growth and development". The Sattvavjaya chikitsa also works on the same grounds as modern psychotherapy. It is full-fledged, nonpharmacological psychotherapy described in ancient literature. Acharya Charaka was the first scholar to use the term "Sattvavajaya". Acharya Charaka mentioned the Sattvavajaya chikitsa only in one chapter of his classic text. While we find traces of this form of chikitsa all over the Charaka Samhita. Sattvavajaya chikitsa can be a key to the empowerment of people in mental faculties as it is a holistic nonpharmacological approach and has various basic techniques to encourage personal development by involving the person himself.

The word Sattvavajaya comprises of "Satva" and "Avajaya". The word Satva is derived from the Sanskrit root "Sat" by the addition of a suffix 'Ktva'. The word 'Avajaya' means victory or conquers. Thus, Sattvavajaya means overcoming of mind or victory over mind or control of the mind. Sattvavajaya therapy aims at the control of the mind by restraining the mind from desires for wholesome objects which are achieved by increasing Satva to subdue the vitiated Manasa dosha i.e. Rajasa and Tamasa. Asatmendriyartha samyoga is regarded as one of the principal causes of disease. So, avoidance of Ati, Hina and Madhya Yoga of Chintya, Vicharya, Uhya, Dhyeya and Sankalpa will serve as the treatment of the psychiatric disorders. Sattvavjaya chikitsa mainly focuses on the consciousness, intelligence, memory as well as spiritual aspects of individuals aiming at altering and discriminating the maladaptive thoughts/actions.

The Mind is a special entity and is complex. It is responsible for our memory, emotional capability, intellect and behaviour. The mind can be a creative as well as a destructive force, so it needs to be tamed and restrained to work constructively. The increasing amount of competition and stress in this ever- 
growing world is consuming the mental faculties and disrupting the normal functioning of the mind. The Sattvavajaya chikitsa mentioned in the ancient literature can help us in maintaining the balance of our Minds. As the technique of this chikitsa is not just for the diseased person, it can be useful as a preventive measure too.

\section{MATERIAL AND METHODS:}

Sattvavajaya chikitsa: The Ayurvedic Psychotherapy

Acharya Charaka has mentioned various techniques about Sattvavajaya chikitsa all over the classical text. The techniques useful in the maintenance of Mental Health are being mentioned below:

a) Mano Nigraha

b) Dharniya vega

c) Avoidance of Prajnaparadha

d) Sadvrutta

e) Aachar rasayana

f) Principles of Sattvavajaya chikitsa.

a) MANO-NIGRAHA:

The definition of Sattvavajaya chikitsa mentions ManoNigraha as the technique to control the Mind. The ManoNigraha includes the following dimensions:

1) Chintya- It refers to the thought process and represents the thinking aspect of the same. As improper thinking influences the process of our decision making resulting in an improper act, the thinking process must be taken utmost care of.

2) Vicharya- It refers to analyzing thoughts and ideas. The thought process i.e. chintyam gets analysed by Vicharya by all aspects and a logical dispute is formed.

3) Uhya- It refers to channelling presumptions with logical reasoning. It is a judgement made by considering all the aspects of the given situation.

4) Dhyeya- It refers to polishing the objectives by concentrating on them.

5) Sankalpa- It refers to taking proper advice for the right decision. It represents a definite determination.

b) DHARNIYA VEGA:

An intelligent person should control the following Manasika Vega (Psychological urges)- (Ch. Su.7/27)
1) Lobha (Greed)

2) Shoka (Grief)

3) Bhaya (Fear)

4) Krodha (Anger)

5) Mana (Egoism)

6) Nairlajja (Shamelessness)

7) Irsha (Jealousy)

8) Atiraga (Excessive affliction)

9) Abhidhyay (Desire to acquire someone else's wealth).

c) AVOIDANCE OF PRAJNAPARADHA (INTELLECTUAL BLASPHEMY): (Ch. Su.11/39)

Prajnaparadha means the errors of Prajna. The term Prajna is a comprehensive term involving three faculties of Mind: Dhi, Dhriti and Smriti. Dhi means the Understanding or Buddhi. Dhriti means the Will to control self from wrong deeds. Smriti means the Memory to recollect whenever necessary. Anything done due to failure of the above mentioned three is counted as Prajnaparadha (Intellectual Blasphemy) which is a cause for many diseases.

Action includes verbal, mental and physical activities. The atiyoga (excess action) includes speech, mind and body activities excessively and their complete inactivity is ayoga (non-utilization).

a) Atiyoga of body activities: Suppression of natural urges, their forceful manifestation, slipping from uneven places, excessive walking, falling, keeping body parts in improper posture, keeping body parts unhygienic, body assault, excessive massage, excess holding of breath and giving all kind of torture to the body are the examples of wrong utilization of body activities.

b) Atiyoga of speech: Backbiting, lying, unnecessary quarrels, unpleasant talks, irrelevant and unpleasant harsh talks are the examples of wrong utilization of speech.

c) Atiyoga of mind activities: Fear, grief, anger, greed, confusion, pride, envy and misconceptions are wrong utilization of mind.

The Dharniya vega mentioned earlier and the atiyoga of mind activities are both on similar grounds. As these emotions can cause overburdening of thoughts 
and later lead to instability in mental activities, they need to be avoided. Avoidance of these intellectual defects helps us in managing our cognitions well which in turn helps us to develop as well as maintain our stability of Mind, which is the ultimate aim.

\section{d) SADVRUTTA:}

Mano Buddhi (perception) causes normal and abnormal perceptions respectively. For the preservation of the normal mind, one should make efforts to maintain the normalcy of sense organs with the mind and protect them from any kind of trauma. This can be achieved by proper association of sense organs and their objects, the performance of duties after duly considering pros and cons with the help of the intellect together with sense organs and by following preventive measures opposite to the qualities of place, season, and own constitution. Thus, anyone who desires the well-being of his own must always remember and follow all the codes of conduct.

Sadvrutta (Code of Conduct) serves many purposes simultaneously, namely, it helps in gaining positive health and also helps in gaining control over our senses. The complete guidelines for the code of conduct include various areas of our daily activities like a cleansing of the body, basic and pleasant attire, and the presentable look as well as to be free from anxiety and fear like emotions and having a positive attitude. The various forbidden codes of conduct imply on us to be virtuous, while the etiquettes for eating, following natural urges, codes for studying and learning as well as the codes for social behaviour and maintaining a good psyche in society helps us in maintaining our well-being. The code of conduct also teaches us to be compassionate towards life and have a higher aim of attaining peace in life.

Thus, following the Sadvrutta (code of conduct) is the path towards a virtuous life and peaceful wellbeing.

\section{e) ACHARA RASAYANA:}

Acharya Charaka has mentioned Achara Rasayana as a pre-requisite for Rasayana Therapy. If Achara Rasayana has benefits in maintaining a positive impact on the Mind, it can be inculcated as a daily regimen too.
Achara Rasayana means an individual who is truthful, free from anger, abstaining from wine, nonviolent, relaxed, calm, soft-spoken, engaged in meditation and cleanliness, perseverance, observes charity, compassionate, vigilant, self-restrained and has a positive mindset can be mentally healthy for a lifetime. Achara Rasayana might sound like a spiritual pathway, but it is the most practical conduct to help in the process of our cognitions.

\section{f) PRINICIPLES OF SATTVAVAJAYA CHIKITSA:}

Sattvavajaya Chikitsa is based on the following 5 techniques:

1) Jnanama- It means the knowledge of spirituality or true understanding. It solely aims at changing the wrong methods of cognitions by gaining a proper and true understanding of life. It includes recognizing and correcting the negative automatic thoughts.

2) Vijnanam- It refers to worldly knowledge or scriptural knowledge. It includes knowledge about activities, our body and mind relationship, dietary regimen and rules, code of conduct, social behaviour as well as personal behaviour. It can be compared to the behavioural techniques used in modern psychotherapy.

3) Dhairya- It means patience. It includes calming down the agitated or vitiated state of Mind indirectly increasing the patience of the person either for counselling (Ashvasana) or meditation techniques. It gives the person the courage to bear the challenges of life.

4) Smriti-It means memory. It refers to reviving the known knowledge or recalling the past experiences to understand them, analyze them and use them in our present as strength.

5) Samadhi- It means meditation or complete concentration. This is a state of mind which is achieved when our mind has abstained from the indulgence of the materialistic world. Samadhi is nothing but the philosophical pathway to attain the highest form of mental stability. 


\section{DISCUSSION}

Sattvavajaya Chikitsa is the non-pharmacological, therapeutic technique that is mentioned in the classical text for the management of mental disorders. It is the technique that focuses on the control of the mind or refraining the mind from undesired objects. As the complete description of Ayurvedic Psychotherapy mentions its utility is not only just in mental disorders but also in systemic disorders. The one-track cognition of using this treatment model just for treating disease might be slightly incorrect. The broader concept of using the principles and dimensions of Sattvavajaya Chikitsa in day-to-day life is a way to manage and cope with the challenges in life.

The ancient classical texts were not the first to describe these psychotherapeutic techniques. They were initially also available in spiritual and philosophical compendia like Shrimad Bhagavata Gita. Mahabharata is a great textbook on psychopathology and Bhagavata Gita is a great treatise in psychotherapy. Bhagavad Gita describes various aspects of psychotherapeutic techniques through 18 chapters of selfknowledge. Gita provides an insight into one's soul and helps to develop oneself and his work. Many of these techniques are also mentioned and preached by Lord Buddha. The Buddha elaborates on controlling the mind in another section of 'Dhammapada': 'Just as an archer straightens his arrow, a wise person straightens His restless and unsteady mind, which is difficult to guard and control and explained the path of purification of mind. Buddha constitutes mainly 3 steps: (1) Sheel (or Sila) meaning morality (2) $\mathrm{Sa}$ madhi meaning meditation, keeping mind attentive within self (3) Panna (Sanskrit pragya) meaning attaining Trance states \& the resultant understanding of spirituality/transcendental. Vipassana is the great path of meditation as taught by Lord Buddha. The word Vipassana is mentioned everywhere in the original language of Buddha in Pali Tipitaka as Vipassana, Vipashyana, passati etc.

As the application of the Sattvavajaya Chikitsa is not mentioned, we can try and apply this module to our daily habits. The code of conduct and Achara Rasayana both have a basic and easy methodology to gain a peaceful mindset. Dharniya vega is the concept to be engaged in our behavioural patterns. The utilization of these techniques will assist our Minds to develop a virtuous mindset and will aid to build integrity.

Thus, emphasizing having a positive attitude and compassion towards life, this treatment model can be used by every individual to increase the quality of life.

\section{CONCLUSION}

Sattvavajaya chikitsa i.e Ayurvedic Psychotherapy holds immense power to be useful to humankind. It can aid in developing a steady and coherent equilibrium between the human body with his/ her mind as well as with the surrounding environment. The utility also aids in decreasing the occurrence of mental diseases and in leading a productive and better life. When people will think positively then they will feel better and automatically people will behave nicely.

\section{REFERENCES}

1. Vd. Kushwah H, Charak Samhita: Ayurved Dipika Ayushi Hindi Commentary, 1st edition, Chaukhamba Orientalia, Varanasi (U.P.) 2005.Cha. Su.1/58

2. Vd. Kushwah H, Charak Samhita: Ayurved Dipika Ayushi Hindi Commentary, 1st edition, Chaukhamba Orientalia, Varanasi (U.P.) 2005.Cha. Su.7/27

3. Vd. Kushwah H, Charak Samhita: Ayurved Dipika Ayushi Hindi Commentary, 1st edition, Chaukhamba Orientalia, Varanasi (U.P.) 2005.Cha. Su.11/39

4. Vd. Kushwah H, Charak Samhita: Ayurved Dipika Ayushi Hindi Commentary, 1st edition, Chaukhamba Orientalia, Varanasi (U.P.) 2005.Cha. Su.11/54

5. Vd. Kushwah H, Charak Samhita: Ayurved Dipika Ayushi Hindi Commentary, 1st edition, Chaukhamba Orientalia, Varanasi (U.P.) 2005.Cha. Su.8/17

6. Vd. Kushwah H, Charak Samhita: Ayurved Dipika Ayushi Hindi Commentary, 1st edition, Chaukhamba Orientalia, Varanasi (U.P.) 2005.Cha. Chi.1/4-34

7. www.euro.who.int > assets > pdf_file> Factsheet_MNH_Empowerment

8. Belaguli G, Savitha HP. An empirical understanding of the concept of Sattvavajaya Chikitsa (Ayurveda Psychotherapy) and a mini-review of its research update. Indian J Health Sci Biomed Res 2019; 12:15-20. 
9. Behere PB, Das A, Yadav R, Behere AP. Ayurvedic concepts related to psychotherapy. Indian J Psychiatry 2013; 55:310-4

10. Bagali SS, Baragi UC, Deshmukh RA. Concept of Satwavajaya Chikitsa (Psychotherapy). J Ayurveda Integr Med Sci 2016;1(1):56-63.

11. J S Tripathi. Dimensions of Sattvavajaya chikitsa (Ayurvedic-psychotherapy) and Their Clinical Applications. Annals Ayurvedic Med.2012: 1(1 \& 2) 31-38.

12. Kamble Samiksha Shankar\& Kaknurkar Vrinda: A Literary Review of Manas Roga According to Ayurveda. International Ayurvedic Medical Journal \{online\} 2018 \{cited March, 2018\}

13. Balaji Deekshitulu P V. Psychiatry in Ayurveda.American Journal of Psychiatric Research and Reviews, 2018, 1:6

14. Kajaria Divya, An Introduction to Sattvavajaya: Psychotherapy in Ayurveda. UJAHM 2013, 01 (01): Page 10-13.

15. Dr Anil Badhoria, Dr Y.K Sharma Role of Ayurveda in the Management of Manas Roga (Mental Disorders): A Review; IRJAY; January 2021, Vol 4; Issue $1 ; 221-228$

\section{Source of Support: Nil Conflict of Interest: None Declared \\ How to cite this URL: Desai Tanvi Prashant et al: Empowerment Of Mental Health Through Sattvavjaya Chikitsa. International Ayurvedic Medical Journal \{online\} 2021 \{cited July, 2021\} Available from: http://www.iamj.in/posts/images/upload/3031_3036.pdf}

